\title{
PERBANDINGAN KINERJA NPL SERTA FAKTOR-FAKTOR YANG MEMPENGARUHI
}

\author{
Mulia Alim', Hesty Erviani Z² \\ Universitas Muhammadiyah Tangerang \\ alimI7mt@gmail.com', hesty.erviani@umt.ac.id²
}

Keyword
Bad Credit, Financial Ratio, NPL

\section{Abstract}

Non performing loans are defined as risks associated with the likelihood of failure of the client to pay its obligations or the risk that the debtor can not repay the debt. NPLs reflect credit risk, the smaller the NPL the less the credit risk borne by the bank. In order for the bank's value to this ratio to be good, Bank Indonesia sets the net NPL ratio below 5\%. In addition to domestic and foreign economic problems, it turns out that some of the financial ratios held by the Bank can give effect to the change in NPL value at Commercial Banks. This study aims to analyze the influence of liquidity and solvency ratios (LDR, LAR and DER), the amount of credit, inflation rate and $B I$ Rate to the ratio of nonperforming loans (NPL) to commercial banks and simultaneously analyze the comparison of NPL Performance in state-owned Commercial Banks (BUMN) with Private Banks domestic (BSDN).

\section{PENDAHULUAN}

Industri perbankan merupakan industri yang syarat dengan risiko, terutama karenamelibatkan pengelolaan dana masyarakat dan diolah dalam bentuk berbagai investasi, sepertipemberian kredit, pembelian surat-surat berharga dan penanaman dana lainya (Ghozali, 2014).Bank merupakan lembaga keuangan yang berfungsi sebagai financial intermediary diantara pihak yang memiliki kelebihan dana dengan pihak yang kekurangan dana, dan dituntut akan prinsip kehati-hatian dalam mengelola dana pihak ketiga maupun dari sumberdana lainnya.

Prinsip kehati-hatian Bank mengharuskan internal Bank menganalisis lebih dalam terhadap alokasi dana yang dilakukan. Alokasi dana adalah menjual kembali dana yang diperoleh dari penghimpunan dana dalam bentuk simpanan (Kasmir, 1999). Alokasi dana Bank yang dilakukan berupa earning asset (aktiva yang meghasilkan) dan non earning asset (aktiva yang tidak menghasilkan). Pengalokasian dana bank dapat berupa pinjaman atau kredit dan dapat pula berupa pembelian asset yang dianggap menguntungkan bagi bank. Kredit adalah salah satu alokasi dana yang dilakukan Bank kepada nasabah peminjam dalam hal ini adalah masyarakat dan perusahaan, dengan harapan mendapatkan keuntungan atas bunga kredit yang dibayarkan oleh nasabah. Namun dalam praktiknya dilapangan, pihak Bank selalu dihadapkan pada masalah besar yaitu kredit tak tertagih atau kredit bermasalah, dimana pihak peminjam wanprestasi terhadap kreditnya kepada Banksehingga akan menurunkan kinerja keuangan Bank tersebut.

Artikel penelitian ini penting karena NPL (non performing loan) atau disebut juga rasio kredit bermasalah, merupakan fokus utama dari lembaga keuangan di seluruh dunia setelah terjadinya krisis ekonomi tahun 2008 juga titik fokusnya adalah cara untuk meminimalkan dampak dari faktor yang mempengaruhi tingkat NPL serta mengurangi tingkat NPL itu sendiri (Meka, 20I5). Artikel ini memberikan gambaran dan perbandingan antara bank umum swasta dengan bank BUMN di Indonesia sehingga diharapkan dapat memberikan masukan kepada 
masyarakat luas mengenai perbandingan tersebut.

Non Performing Loan (NPL) adalah salah satu indikator kunci untuk menilai kinerja fungsi bank, karena NPL yang tinggi adalah indikator gagalnya bank dalam mengelola bisnis antara lain timbul masalah likuiditas (ketidakmampuan membayar pihak ketiga), Rentabilitas (utang tidak bisa ditagih), Solvabilitas (Modal berkurang). Sedangkan laba yang merosot adalah salah satu imbasnya karena praktis bank kehilangan sumber pendapatan di samping harus menyisihkan pencadangan sesuai kolektibilitas kredit. Selektifitas dan kehati-hatian yang dilakukan manajemen dalam memberikan kredit dapat mengurangi risiko kredit macet, oleh karena itu diperlukan manajemen yang baik agar memiliki kinerja NPL yang baik.

Rasio NPL merupakan rasio untuk mengukur kemampuan bank dalam menjaga resiko kegagalan pengembalian kredit oleh debitur (Komang, 2004).Kredit bermasalah didefinisikan sebagai risiko yang dikaitkan dengan kemungkinan kegagalan klien membayar kewajibannya atau risiko dimana debitur tidak dapat melunasi utangnya.NPL mencerminkan risiko kredit, semakin kecil NPL semakin kecil pula resiko kredit yang ditanggung pihak bank. Agar nilai bank terhadap rasio ini baik Bank Indonesia menetapkan kriteria rasio NPL net di bawah 5\%. Berdasarkan data, Tingkat NPL perbankan selama tahun 2005-2007 berkisar 5, I persen sampai dengan 9,5 persen. Padahal, tingkat NPL yang disyaratkan Bank Indonesia sebesar 5 persen.

Tingginya risiko kredit telah menyebabkan tingkat profitabilitas bank cenderung turun dan stagnan. Beda dengan tahun 2007, Rasio kredit bermasalah (non performing loan/NPL) gross industri bank umum pada Juni 2014 tercatat 2,08\%, naik dibandingkan dengan posisi NPL pada Mei 2014 sebesar 1,96\%. Adapun, NPL nett padaJuni 2014 tercatat I,I2\%, naik dibandingkan dengan posisi pada Mei 2014 sebesar I,0I\%. Kenaikan rasio NPL, lanjutnya, di antaranya dipengaruhi melambatnya pertumbuhan ekonomi nasional sehingga menurunkan kemampuan kreditur untuk membayar angsuran. Melambatnya pertumbuhan ekonomi juga dibarengi akibat terjadinya inflasi dalam negeri yang mengakibatkan pada kenaikan harga barang-barang secara umum, dan ini juga dipicu akibat adanya kenaikan BBM setiap tahunnya dan juga tingkat suku bunga Bank Indonesia yang tinggi menyebabkan pada geliat bisnis maupun sisi konsumtif masyarakat menjadi menurun. Selain permasalahan ekonomi nasional, tinggi rendahnya rasio NPL juga mungkin disebabkan oleh beberapa rasio keuangan yang harus diperhatikan oleh pihak Bank. Beberapa diantaranya adalah Loan to Deposit Ratio(LDR), Loan to Asset Ratio (LAR) dan Debt to equity ratio (DER).

\section{TINJAUAN PUSTAKA}

\section{Bank}

Sektor perbankan berfungsi untuk kemantapan mikroekonomi dan makroekonomi serta dalam pertumbuhan ekonomi. Pada tingkat mikroekonomi, perbankan berfungsi sebagai sumber daya dana sedangkan pada makroekonomi, perbankan untuk menambah kekuatan sistem ekonomi suatu negara (Ali \& Akhtar, 20II). Menurut (Jacob, 2013) lembaga perbankan merupakan lembaga keuangan yang memiliki sifat khusus dari sudut pandang mikro dan makro.Dari sudut pandang makro, lembaga perbankan sebagai penyalurjasa kredit sehingga mampu menstimulasi roda perekonomian suatu negara.Sedangkan darisudut pandang mikro adalah lembaga yang menetapkan kebijakan moneter.Dengan demikian perusahaan perbankan memiliki peran penting bagi kemajuan perekonomian di suatu negara.

Bank adalah lembaga kepercayaan yang berfugsi sebagai lembaga intermediasi yaitu yang membantu kelancaran pembayaran dan sarana dalam pelaksanaan kebijakan pemerintah, yaitu kebijakan moneter (Margaretha dan Setianingrum, 20II). Intermediasi keuangan adalah pengalihan kegiatan dana dari penabung kepada peminjam (Buchory,20I4).

Menurut M. Sinungan (1992), dana-dana bank yang digunakan sebagai modal operasional, bersumber dari :

a. Dana dari modal sendiri atau yang sering disebut juga dana dari pihak I, yaitu dana dari modal bank sendiri

b. Dana pinjaman dari pihak luar atau dana pihak ke II, yaitu pihak yang memberikan pinjaman dana kepada bank

c. Dana dari masyarakat atau dana pihak ke III, yaitu dana-dana masyarakat yang disimpan dalam bank adalah merupakan sumber dana yang terbesar yang paling diandalkan bank dan terdiri dari 3 jenis, yaitu Giro (demand deposits), Deposito (time deposits), dan Tabungan (saving).

Setelah sumber dana diperoleh Bank, maka selanjutnya Bank akan mengalokasikan dananya ke posko keuangannya. Alokasi 
danaadalah menjual kembali dana yang diperoleh dari penghimpunan dana dalam bentuk simpanan (Kasmir, 1999). Pengalokasian dana bank dapat berupa pinjaman atau kredit dan dapat pula berupa pembelian asset yang dianggap menguntungkan bank. Adapun alokasi dana bank dapat dibagi menjadi 2 (dua) yaitu:

a. Non earning asset $s$ (aktiva yang tidak menghasilkan), terdiri dari :

I. Primary reserve, berbentuk uang tunai dalam kas dan uang tunai dalam saldo rekening di Bank Indonesia. Dana-dana dalam Primary reserve adalah untuk kepentingan cash ratio atau penjagaan posisi likuiditas bank berdasarkan peraturan dari Bank Indonesia selaku bank sentral.

2. Penanaman dana dalam aktiva tetap dan inventaris, adalah penanaman dana dalam bentuk seperti gedung kantor, peralatan-peralatan kantor baik yang manual maupun yang canggih dengan teknologi super modern. Semua itu demi menjaga standing bank dalam konstelasi perekonomian dan perbankan. Dan ini umumnya berasal dari modal awal dan dari cadangan modal bank.

b. Earning Asset (asset yang menghasilkan), terdiri dari :

I. Secondary reserve, merupakan alokasi dalam bentuk surat-surat berharga dan ataupun aktiva lancar lainnya yang menghasilkan.

2. Kredit, menurutPeraturan Bank Indonesia Nomor: I4//5/PBI/20I2 TentangPenilaian Kualitas Aktiva Bank Umum menyatakan bahwa Kredit adalah penyediaanuang atau tagihan yang dapat dipersamakan dengan itu, berdasarkan persetujuan atau kesepakatan pinjam meminjam antara Bank dengan pihak lain yang mewajibkan pihak peminjam untuk melunasi utangnya setelah jangka waktu tertentu dengan pemberian bunga.

\section{Kinerja Keuangan}

Untuk menilai kondisi keuangan dan prestasi perusahaan maka dibutuhkan beberapa tolak ukur yang dinyatakan dengan rasio dan indeks, yaitu yang menghubungkan dua data keuangan antara satu dengan yang lain (Sawir, 2005).

Menurut (Sahara, 20I3) kinerja keuangan bank adalah suatu ukuran yang menggambarkan kondisi keuangan suatu bank. Bagi nasabah, ketika akan mendepositokan dananya di suatu bank akan melihat lebih dahulu kinerja bank melalui laporan keuangan yang dihasilkan. Penilaian kinerja membantu, baik bank dan para pemangku kepentingan untuk menilai hasil dari kebijakan bank dan operasi dalam moneter.

Beberapa alat ukur kinerja perusahaan dapat dilihat dari kinerja likuiditas dan solvabilitas. Likuiditas menunjukkan kemampuan bank untuk memenuhi kewajiban keuangan secara tepat waktu dan dengan cara yang efektif (Kumbirai \& Webb, 2010). Samad, 2004 menyatakan bahwa Likuiditas adalah kehidupan dan darah bagi bank komersial. Rasio likuiditas dari sebuah perusahan perbankan antara lain Loan to Deposit Ratio (LDR) dan Loan to Asset Ratio(LAR) (Kumbirai \& Webb, 2010). Sedangkan rasio solvabilitas merupakan kemampuan perusahaan memenuhi kewajibannya. Salah satu rasio solvabilitas yang digunakan dalam penelitian ini adalah DER (debt to equity ratio) adalah rasio perbandingan antara utang dengan modal pemegang saham (Narasimhan \& Goel, 20I3). Secara teori dapat dijelaskan sebagai berikut:

\section{Loan to Deposit Ratio (LDR)}

Loan to deposit Ratio (LDR) adalah rasio kemungkinan adanya deposan atau debitur menarik dananya dari bank (Sudiyatno \& Suroso,2010). Sedangkan menurut (Aini, 2013) menyatakan bahwa LDR merupakan rasio yang menunjukkan tingkatlikuiditas suatu bank dan kemampuan bank menjalankan sebagai fungsi intermediasinya dalam menyalurkan dana pihak ketiga ke kredit. Resiko penarikan dana ditentukan oleh, masing-masing likuiditas. Giro mempunyai likuiditas ynag tinggi karena dana dapat ditarik sewaktu-waktu sehingga bank harus dapat memproyeksi kebutuhan likuiditasnya untuk memenuhi nasabah giro. Sementara dalam hal deposito Berjangka resikonya relatif lebih rendah karena bank dapat memproyeksikan likuiditas yang dibutuhkan untuk memenuhi penarikan Deposito berjangka yang telah jatuh tempo (Sudiyatno \& Suroso,20 I0).

\section{Loan to Asset Ratio(LAR)}

Loan to Asset s Ratio (LAR) merupakan rasio untuk mengukur likuiditas bankdisamping dapat menggunakan rasio LDR.Perbedaan diantara kedua rasio tesebut adalahkalau LDR merupakan rasio likuiditas bank diukur 
dengan deposito sedangkan LARlikuiditas bank diukur dengan total aset. Bank dengan LAR yang rendah akan memilikitingkat likuiditas yang lebih besar jika dibandingkan dengan LAR yang lebih rendah.Namun, tingkat LAR yang tinggi mengindikasikan tingkat profitabilitas potensial yangtinggi dengan tingkat risiko yang tinggi pula (Paul et al., 20I3).

\section{Non Performing Loans (NPL)}

NPL digunakan untuk pengukuran resiko bank yang berkaitan dengan resikopemberian kredit dan resiko nilai indeks dalam pengembalian aset (Ahmad et al.,2008).Dengan NPL ini diharapkan dapat membantu pembuat keputusan lebihmemperhatikan kegiatan yang relevan yang dapatmemberikan dampak potensial dan kuatpada kinerja perbankan (Alkhatib, 20I2).Modal bank dipengaruhi oleh pengambilankredit dan pendapatan ekonomi yang berkaitan dengan efisiensi dan kemungkinanlikuidasi (Margaretha dan Setianingrum, 20I I).

Aini, 2013 menyatakan bahwa NPL merupakan rasio untuk mengukur kemampuan bank dalam menutupi resiko pengembalian kredit oleh debitur. Rasio NPLdihitung dengan cara membandingkan antara kredit bermasalah terhadap total kredit. NPL memiliki bubungan terbalik dengan perubahan laba.

\section{Debt to equity ratio(DER)}

Tingkat risiko keuangan terbentuk dari kombinasi tertentu yang terdiri dari sahambiasa, saham preferen dan utang digunakan untuk mendanai aset suatu perusahaan.Tingkatleverage yang optimal harus ditentukan dan dikelola oleh perusahaan untukmemastikan tingkat risiko pembiayaan tidak melampaui batas, yang akan menyebabkanhasil yang rendah untuk pemegang saham (Ebiringa et. Al., 20I2).DER adalah rasioperbandingan antara utang dengan modal pemegang saham (Narasimhan \& Goel, 20I3).

\section{Ekonomi Makro}

\begin{tabular}{llr}
\multicolumn{1}{c}{ Lingkungan ekonomi makro akan } \\
mempengaruhi & operasional perusahan \\
dalampengambilan & keputusan untuk suatu \\
kebijakan yang berkaitan dengan kinerja \\
keuanganperbankan (Sahara, 20I3). Variabel \\
ekonomi makro yang dijadikan dalam penelitian
\end{tabular} ini adalah inflasi dan tingkat suku bunga Bank Indonesia.

\section{Inflasi}

Tingkat inflasi yang tinggi dapat diartikan bahwa indeks harga konsumenakanmenyebabkan ketidakstabilan bagi perekonomian secara makro dan akan beresiko kepadabank sehingga dapat menurunkan profitabilitas bank (Hasan et al., 20I3).Lemahnya lingkungan makroekonomi menjadi alasan mengenai pertumbuhanekonomi yang rendah serta inflasi yang tinggi sehingga menyebabkan tidak adanyapertumbuhan perekonomian (Ali \& Akhtar, 20l I)

\section{BI Rate}

Lingkungan ekonomi makro akan mempengaruhi operasional perusahaan dalam pengambilan keputusan untuk suatu kebijakan yang berkaitan dengan kinerja keuangan perbankan (Sahara, 20I3). Variabel ekonomi makro antara lain mencakup inflasi dan tingkat suku bunga Bank Indonesia; a) Inflasi, Tingkat inflasi yang tinggi dapat diartikan bahwa indeks harga konsumen akan menyebabkan ketidakstabilan bagi perekonomian secara makro dan akan beresiko kepada bank sehingga dapat menurunkan profitabilitas bank (Hasan et al., 20I3). Lemahnya lingkungan makroekonomi menjadi alasan mengenai pertumbuhanekonomi yang rendah serta inflasi yang tinggi sehingga menyebabkan tidak adanyapertumbuhan perekonomian (Ali \& Akhtar,20II); b) BI Rate, untuk menjaga kestabilitasan perekonomian diperlukan suatu lembaga sebagaipengawas dan pengatur salah satunya bagi lembaga perbankan sehingga kepercayaan nasabah dapat terjaga yaitu Bank Indonesia (Jacob, 20/3). Di Indonesia yang menjadisuku bunga kebijakan Bank Indonesia adalah suku bunga BI yang menjadi acuan suku bunga di pasar uang (laporan Bank Indonesia, 20/2).BI rate menjadi acuan untuk suku bunga deposito, suku bunga pasar uang antar bank (PUAB) dan suku bunga kredit dan dinyatakan dalam persen (Sahara, 2013).

\section{Hipotesis \\ Pengaruh LDR terhadap NPL}

LDR mencerminkan dana yang dihimpun oleh bank yang berasal dari masyarakat dalam bentuk deposito, giro, dn tabungan yang disalurkan kembali dalam bentuk kredit atau 
pinjaman. Rasio LDR juga digunakan untuk seberapa besar pemberian kredit oleh satu bank. Kegiatan utama bank adalah penyaluran kredit. Kredit yang disalurkan oleh bank semakin besar maka membawa konsekuensi yang semakin besarnya risiko yang ditanggung oleh bank yaitu adanya risiko adanya kredit bermasalah diantara kredit yang disalurkan kepada masyarakat. Dengan demikian semakin besar LDR maka semakin besar pula NPL suatu bank. Dari uraian di atas maka hipotesis dalam penelitian ini di rumuskan sebagai berikut:

HI: LDR berpengaruh terhadap NPL pada bank perusahaan Perbankan

\section{Pengaruh DER terhadap NPL}

Debt to equity ratio merupakan perbandingan utang terhadap modal atau rasio yang dipergunakan untuk mengukur tingkat penggunaan utang terhadap total shareholder's equity yang dimiliki perusahaan. Namun di perbankan, penggunaan utang lebih didominasi dari adanya dana pihak ke tiga, karena sebagian besar dana yang dikelolanya adalah dana pihak ketiga (masyarakat). Semakin besar dana pihak ketiga yang dikelola oleh Bank, maka kemungkinan untuk mendapat laba usaha juga semakin tinggi, sehingga berdampak pada alokasi kredit meningkat. Namun peningkatan alokasi kredit tersebut juga menimbulkan efek pada resiko tak tertagih, akibat dari banyaknya nasabah yang wanprestasi. Dengan demikian hipotesis yang dikemukakan adalah sebagai berikut:

H2 : DER berpengaruh terhadap Non Performing Loan (NPL) pada perusahaan Perbankan

\section{LAR terhadap NPL}

Tingkat LAR mengukur tingkat likuiditas sebuah perusahaan seperti halnya LDR. Tingkat LAR yang tinggi mengindikasikan tingkat profitabilitas potensial yang tinggi dengan tingkat risiko yang tinggi pula (Paul et al., 20/3). Tingginya tingkat LAR mengindikasikan semakin tinggi maka tingkat risiko yang ditanggung oleh bank sehingga akan menyebabkan meningkatnya tingkat NPL yang tinggi pula dikarenakan adanya kemungkinan perusahaan mengalami ketidakmampuan membayar kredit. Dengan demikian hipotesis yang dikemukakan adalah sebagai berikut:

H3 : LAR berpengaruh terhadap NPL pada perusahaan Perbankan

\section{Kredit yang diberikan terhadap NPL}

Pemberian kredit harus melihat perihal dari pihak debitur. Pihak bank melakukan survey terlebih dahulu untuk mengetahui watak (character), kemampuan (capacity) modal (capital), anggunan (collateral) dan kondisi ekonomi debitur (condition of economy) (Linda, Megawati \& Deflinawati, 2015). Besarnya kredit yang diberikan akan meningkatkan risiko besarnya kredit yang bermasalah. Dengan demikian semakin tinggi kredit yang diberikan semakin tinggi pula besarnya NPL. Hipotesis yang diajukan adalah sebagai berikut:

$\mathrm{H} 4$ : Kredit yang diberikan berpengaruh terhadap NPL pada perusahaan Perbankan

\section{Inflasi terhadap NPL}

Bank diasumsikan bereaksi berbeda terhadap rasio NPL di atas atau di bawah ambang batas dalam membuat keputusan Kredit (Roy, 20I5). Dengan NPL di atas ambang batas memberikan efek buruk pada pinjaman dan sebaliknya. Pemberian pinjaman oleh bank akan memberikan efek pada kegiatan ekonomi.

Hubungan antara lingkungan makro ekonomi dan kualitas kredit berkaitan dengan fase siklus bisnis ekonomi dengan stabilitas perbankan (Messai \& Joini, 20I3). Siklus bisnis ekonomi terdiri dari dua fase. Pertama adalah fase ekspansi ekonomi ditandai dengan jumlah yang relatif kecil dari kredit macet, perusahaan dan konsumen memiliki pendapatan untuk menutupi utang mereka dalam jangka waktu yang telah ditentukan. Kedua adalah fase resesi, dalam fase ini terjadinya peningkatan kredit macet dikarenakan perusahaan dan konsumen tidak memiliki pendapatan yang cukup untuk memenuhi hutang dalam jangka waktu yang telah ditentukan.

Saba, Kauser, Azeem (20I2) menyatakan bahwa GDP per kapita, inflasi, dan jumlah kredit yang diberikan oleh bank berpengaruh signifikan terhadap NPL.

H5: Inflasi berpengaruh terhadap NPL pada perusahaan Perbankan

\section{Tingkat suku Bunga Bank Indonesia terhadap NPL}

Tingkat suku bunga mempengaruhi jumlah hutang bermasalah ketika suku bunga yang berlaku adalah suku bunga mengembang. Dengan demikian berarti bahwa dampak dari tingkat suku bunga adalah positif terhadap jumlah utang sehingga muncul kredit bermasalah (Bofondi dan Ropele, 20II).Tingginya tingkat suku bunga akan meningkatkan jumlah tagihan 
kredit yang harus dipenuhi oleh debitur. Dengan semakin tinggi tingkat tagihan kredit tersebut maka akan meningkatkan tingkat NPL. Hipotesis yang diajukan dalam penelitian ini adalah sebagai berikut:

H6: BI Rate berpengaruh terhadap Non Performing Loan (NPL)pada perusahaan Perbankan

\section{METODE PENELITIAN}

Jenis data yang digunakan dalam penelitian ini adalah data sekunder yang diambil dari laporan keuangan dari tahun 2007 sampai dengan 2015 yang sudah dipublikasi di Bursa Efek Indonesia (www.idx.co.id), selain itu juga data variable makro ekonomi diambil dari Bank Indonesia dan Biro Pusat Statistik RI. Populasi dalam penelitian ini adalah semua bank umum yang terdaftar di BEl.Teknik pengambilan sampel menggunakan Non probability sampling dengan metode Purposive Sampling (sugiyono,2010).Menggunakan kriteria sampel; I) Perusahaan dalam industri perbankan yang terdaftar di Bursa Efek Indonesia, 2) Perusahaan Perbankan yang termasuk kategori BUMN, 3) Perusahaan perbankan swasta dalam negeri (BSDN) yang termasuk dalam 4 perusahaan perbankan dengan asset terbesar, 4) Perusahaan menggunakan mata uang rupiah,5) Perusahaan menerbitkan laporan keuangan secara lengkap dari periode 2007 sampai dengan 2015.

Tabel I. Sampel perusahaan

\begin{tabular}{|c|l|l|}
\hline No & Bank BUMN & \multicolumn{1}{|c|}{$\begin{array}{c}\text { Bank Swasta D/N } \\
\text { (BSDN) }\end{array}$} \\
\hline I & BRI & BCA \\
\hline 2 & BNI & CIMB Niaga \\
\hline 3 & Mandiri & Danamon \\
\hline 4 & BTN & Permata \\
\hline
\end{tabular}

Variabel yang digunakan dalam penelitian ini terdiri dari; I) Variabel dependen (Variabel Y) yang digunakan dalam penelitian ini adalah NPL (Non Performing Loan) atau Kredit bermasalah, yangdiukur dengan NPL (Non Performing Loan) dan; 2) Variabel independen (variabel $X$ ) yang digunakan dalam penelitian ini adalah Loan to Deposit Ratio (LDR), LAR (Loan to Asset Ratio), DER (Debt to equity ratio), Inflasi, BI Rate dan Kredit yang diberikan.

Metode analisis yang digunakan dalam penelitian ini adalah;

a) $\bigcup_{j i}$ asumsi klasik menggunakan uji normalitas data, multikolinieritas, uji heteros kedastisitas dan autokorelasi; b) Analisis regresi; analisis ini digunakan untuk mengetahui ada atau tidaknya pengaruh perubahan rasio keuangan, inflasi dan $\mathrm{BI}$ Rate (variabel independen) terhadap rasio NPL (variabel dependen). Persamaan regresi yang digunakan adalah persamaan regresi linier yang dihitung dengan : $Y=a+b X$; di mana: $X=$ perubahan modal kerja; $Y \mid=$ tingkat profitabilitas, $Y 2$ = risiko;

c) Uji R2 koefisien determinasi dilakukan untuk melihat seberapa jauh kemampuan model dalam menerangkan variasi variabel bebas mempengaruhi variabel terikat (Ghozali, 2005). Nilai $R^{2}$ berada antara 0 dan $I$. Semakin mendekati I atau 100\% maka semakin besar pengaruh variabel independen terhadap variabel dependen.

d) Uji statistik, untuk menguji apakah pengaruh signifikan atau tidak maka perlu dihitung nilai $\mathrm{t}$ dengan interval keyakinan (level of signification) $95 \%, \alpha=5 \%$ dan derajat kebebasan (degree of freedom).

e) Uji Independent sample $T$ test, digunakan untuk mengetahui ada atau tidaknya perbedaan rata-rata antara dua kelompok sampel yang tidak berhubungan. Jika ada perbedaan, rata-rata manakah yang lebih tinggi. Data yang digunakan biasanya berskala interval atau rasio.

\section{HASIL PENELITIAN DAN PEMBAHASAN}

Berdasarkan grafik di bawah ini, nilai ratarata NPL pada Bank Swasta D/N yang tertinggi yakni pada tahun 2009 yaitu sebesar 3,1\% dan kemudian pada tahun 2015 yakni 2,6\%. Ini menunjukkan bahwa NPL pada Bank swasta $\mathrm{D} / \mathrm{N}$ tidak terlalu tinggi dan masih dibawah $5 \%$.

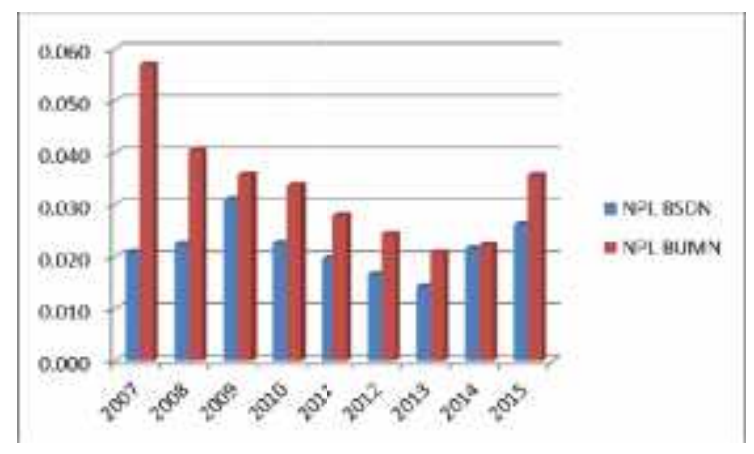

\section{Gambar I. Grafik Perbandingan NPL} pada Bank Swasta D/N dan Bank BUMN

Jika dibandingkan dengan rasio NPL pada Bank BUMN tentu akan terlihat perbedaan yang 
signifikan, dimana rata-rata rasio NPL pada BUMN adalah sebesar 5,7\%, terutama pada tahun 2007 dan nilai secara aturan Bank Indonesia telah melewati batas maksimum NPL yang diperbolehkan yakni sebesar $5 \%$.

Tabel 2. Uji Normalitas Perusahaan Perbankan

\begin{tabular}{l|l|r}
\hline \multicolumn{2}{l|}{} & \multicolumn{1}{|c}{$\begin{array}{c}\text { Unstandardized } \\
\text { Residual }\end{array}$} \\
\hline $\mathrm{N}$ & Mean & $\mathbf{7 2}$ \\
\hline \multirow{2}{*}{$\begin{array}{l}\text { Normal } \\
\text { Parametersa,b }\end{array}$} & $\begin{array}{l}\text { Std. } \\
\text { Deviation }\end{array}$ \\
\hline Most Extreme & Absolute & .01191027 \\
\cline { 2 - 3 } Differences & Positive & .095 \\
\cline { 2 - 3 } & Negative & .078 \\
\hline Kolmogorov-Smirnov Z & -.095 \\
\hline Asymp. Sig. (2-tailed) & .806 \\
\hline
\end{tabular}

Pengujian atas normalitas data pada penelitian ini dilakukan dengan menggunakan uji Kolmogrov-Smirnov. Dari hasil output one sample kolmogorov smirnov, diperoleh nilai asymp.Sig (2tailed) sebesar 0,535 yang berarti lebih besar dari 0,05 , dengan demikian dapat dikatakan bahwa data data dalam penelitan ini berdistribusi normal.

Tabel 3. Uji Multikolinieritas Perusahaan Perbankan

\begin{tabular}{l|l|r|r}
\hline \multirow{2}{*}{ Model } & \multicolumn{2}{c}{ Collinearity Statistics } \\
\cline { 3 - 4 } & Tolerance & \multicolumn{1}{c}{ VIF } \\
\hline \multirow{4}{*}{$\mathrm{I}$} & (Constant) & & \\
\cline { 2 - 4 } & LDR & .760 & 1.316 \\
\cline { 2 - 4 } & DER & .709 & $1.4 \mathrm{II}$ \\
\cline { 2 - 4 } & LAR & .797 & 1.254 \\
\cline { 2 - 4 } & KREDIT & .616 & 1.622 \\
\cline { 2 - 4 } & Inflasi & $.61 \mathrm{I}$ & 1.637 \\
\cline { 2 - 4 } & BI_Rate & .438 & 2.283 \\
\hline
\end{tabular}

Mengacu pada hasil multikolinieritas, dengan nilai tolerance dari seluruh variabel dalam sampel perusahaan perbankan BUMN diatas 0,1 atau $10 \%$ ) dan jika dilihat dari nilai VIF kurang dari 10, maka dapat disimpulkan bahwa antar variabel bebas tidak terjadi multikolinieritas.

Tabel 4. Uji Autokorelasi Perusahaan Perbankan

\begin{tabular}{l|r|r}
\hline Model & R & \multicolumn{1}{c}{ Durbin-Watson } \\
\hline $\mathrm{I}$ & $.535^{\mathrm{a}}$ & .948 \\
\hline
\end{tabular}

Dari hasil pengolahan data di atas, nilai DW test adalah sebesar 0,948 atau dapat dikatakan bahwa $-2<0,948<2$. Dengan demikian dapat disimpulkan bahwa data pada perusahaan perbankan dalam penelitian ini tidak terjadi autokorelasi.

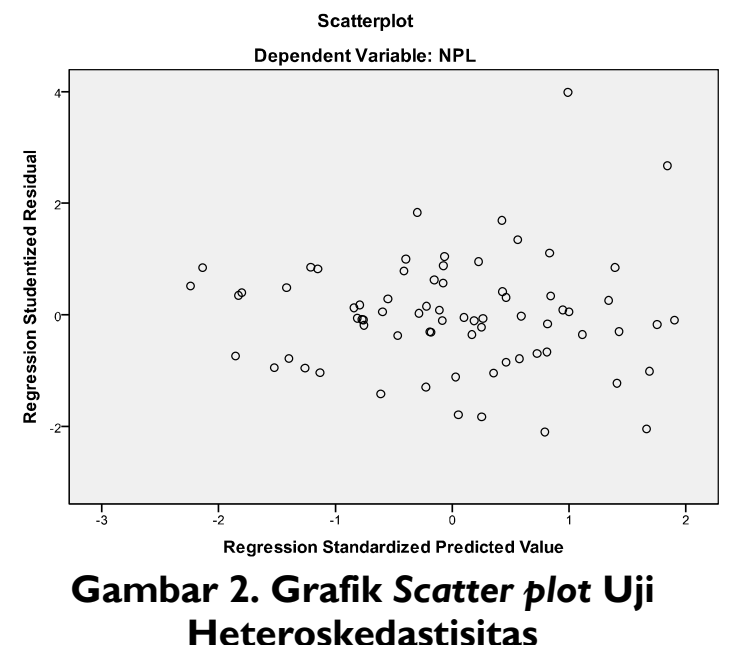

Demikian pula hasil uji heteroskedastisitas menunjukkan bahwa variabel bebas di atas tidak terjadi heteroskedastisitas atau bersifat homoskedastisitas. Hal ini dapat dilihat dari grafik scatterplot di bawah ini, dimana titik-titik menyebar di bawah dan di atas sumbu y dan tidak mempunyai pola yang teratur.

Tabel 5.CoeficientsPerusahaan Perbankan

\begin{tabular}{|c|c|c|c|c|}
\hline \multirow{2}{*}{\multicolumn{2}{|c|}{ Model }} & \multirow{2}{*}{$\begin{array}{l}\text { Unstandardized } \\
\text { Coefficients } \\
\text { B }\end{array}$} & \multirow[t]{2}{*}{$\mathrm{t}$} & \multirow[t]{2}{*}{ Sig. } \\
\hline & & & & \\
\hline $\mathrm{I}$ & (Constant) & -.016 & -.847 & .400 \\
\hline & LDR & .010 & 2.329 & .023 \\
\hline & DER & .001 & .594 & .555 \\
\hline & LAR & .004 & .307 & .760 \\
\hline & KREDIT & $-3.510 \mathrm{E}-\mathrm{II}$ & -2.474 & .016 \\
\hline & Inflasi & -.137 & -1.938 & .057 \\
\hline & Bl_Rate & .587 & 2.517 & .014 \\
\hline
\end{tabular}

Dari hasil pengolahan data, diperoleh persamaan regresi linier berganda sebagai berikut:

$Y=-0,0$ I +0,0 ILDR+0,00 I DER+0,004LAR0,0035 KREDIT-0, I 37INFLASI+0,587BI RATE+e

Hasil persamaan regresi menunjukkan bahwa setiap perubahan rasio NPL sebesar I, menyebabkan pada peningkatan rasio LDR $\left(0,0 \mid x_{1}\right)$, DER $\left(0,00 \mid x_{2}\right)$, LAR $\left(0,004 x_{3}\right)$ dan BI Rate $\left(0,58 x_{6}\right)$, yang artinya memiliki hubungan positif searah. Disisi lain perubahan rasio NPL sebesar I, menyebabkan pada penurunan jumlah kredit $\left(0,003 x_{4}\right)$ dan tingkat inflasi $\left(0,13 x_{5}\right)$. 
Tabel 6. R (Korelasi) Perusahaan Perbankan

\begin{tabular}{l|r|r|r}
\hline Model & R & R Square & \multicolumn{1}{c}{$\begin{array}{c}\text { Adjusted R } \\
\text { Square }\end{array}$} \\
\hline $\mathrm{I}$ & $.535^{\mathrm{a}}$ & .286 & .220 \\
\hline
\end{tabular}

Hasil koefisien determinasi mengacu pada nilai adjusted $\mathrm{R}^{2}$ untuk perusahaan perbankan adalah sebesar 0,286 atau $28,6 \%$. Hal ini berarti NPL dapat dijelaskan oleh LDR, DER, LAR, Kredit, Inflasi, BI Rate.

Pengujian hipotesis $\mathrm{t}$ ini dilakukan dengan menggunakan tingkat signifikansi 5\%. Dimana;

a) LDR memiliki pengaruh signifikan terhadap NPL dengan signifikansi sebesar 0,023< 0,05; sehingga $\mathrm{H}_{1}$ Diterima dan $\mathrm{H}_{0}$ Ditolak

b) DER tidak memiliki pengaruh terhadap NPL dengan signifikansi sebesar $0,555>0,05 ; \mathrm{H}_{2}$ Ditolak dan $\mathrm{H}_{0}$ Diterima

c) LAR tidak memiliki pengaruh terhadap NPL dengan signifikansi sebesar $0,76>0,05 ; \mathrm{H}_{3}$ Ditolak dan $\mathrm{H}_{0}$ Diterima d) Jumlah Kredit memiliki pengaruh yang signifikan terhadap NPL dengan signifikansi sebesar $0,0 \mathrm{I} 6<0,05 ; \mathrm{H}_{4}$ Diterima dan $\mathrm{H}_{0}$ Ditolak

e) Inflasi tidak memiliki pengaruh terhadap NPL dengan signifikansi sebesar 0,057> 0,05; $\mathrm{H}_{5}$ Ditolak dan $\mathrm{H}_{0}$ Diterima

f) BI Rate memiliki pengaruh yang signifikan terhadap NPL dengan signifikansi sebesar $0,014<0,05 ; \mathrm{H}_{6}$ Diterima dan $\mathrm{H}_{0}$ Ditolak

Tabel 7. Uji F, Perusahaan Perbankan

\begin{tabular}{llll}
\hline Model & F & Sig. \\
\hline $\mathrm{I}$ & Regression & 4.338 & $.00 \mathrm{I}^{\mathrm{a}}$ \\
\hline
\end{tabular}

Jika dilihat secara simultan pengaruh likuiditas, solvabilitas, jumlah kredit, tingkat inflasi dan $\mathrm{BI}$ rate terhadap rasio NPL pada bank BUMN dan Swasta D/N menyimpulkan bahwa terdapat pengaruh yang signifikan dengan dibuktikan dari nilai signifikansi sebesar 0,00I < 0,05 . Sehingga persamaan regresi ini layak untuk digunakan berdasarkan pendekatan Anova.

Tabel 8. Uji Beda BSDN \& BUMN

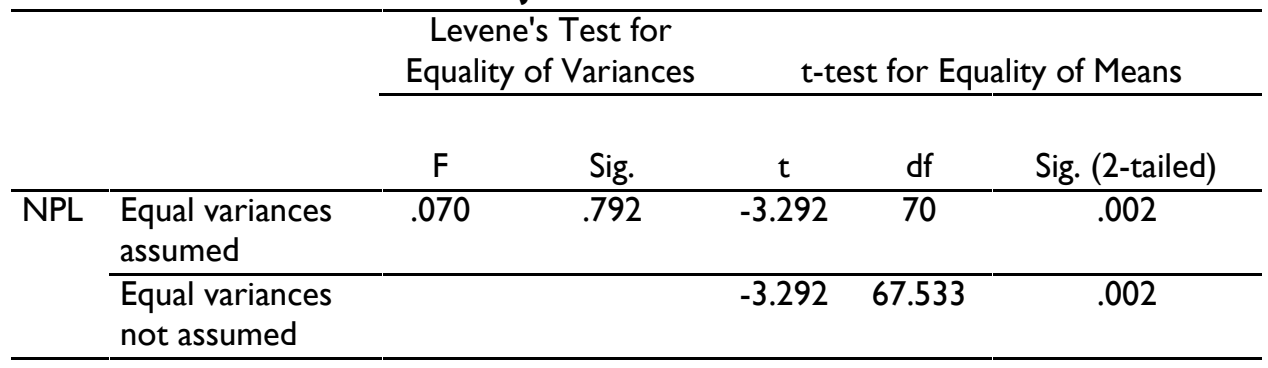

Dengan membandingkan kinerja NPL antara Bank Swasta dan Bank BUMN, maka dapat dilihat apakah terdapat perbedaan yang signifikan terhadap hal tersebut. Berdasarkan tabel di atas, maka dapat dikatakan bahwa terdapat perbedaan yang signifikan antara NPL Bank Swasta Dalam Negeri dengan NPL pada Bank BUMN, ini dibuktikan dari nilai sig(2-tailed) yaitu sebesar 0,002, dengan ketentuan 0,002 < 0,05, Maka dapat disimpulkan Ho ditolak.

\section{PENUTUP}

\section{Kesimpulan}

Berdasarkan hasil pengolahan data, diperoleh rata-rata NPL selama 9 tahun dari tahun 2007 s/d 2015 untuk Bank swasta dalam negeri adalah sebesar 2,16\% dan Bank BUMN sebesar 3,19\%. Hal ini menunjukkan bahwa ratarata NPL di Bank swasta dalam negeri masih lebih rendah/ lebih baik dibandingkan dengan Bank BUMN.

Walaupun demikian rata-rata kinerja NPL pada perbankan swasta dalam negeri dan BUMN selama 9 tahun masih dikatakan cukup baik, oleh karena menurut peraturan PERATURAN BANK INDONESIA NOMOR I7/II/PBI/20I5 Batas atas LFR Target untuk Bank sebagaimana dimaksud memenuhi Rasio NPL Total Kredit secara bruto (gross) kurang dari 5\% (lima persen).

Secara simultan pengaruh likuiditas, solvabilitas, jumlah kredit, tingkat inflasi dan BI rate terhadap rasio NPL pada Perbankan (BUMN dan Swasta D/N) menyimpulkan bahwa terdapat pengaruh yang signifikan dengan dibuktikan dari nilai signifikansi sebesar 0,00I < 0,05. Jika dilihat dari uji beda, penelitian ini menyimpulkan bahwa terdapat perbedaan yang 
signifikan antara kinerja NPL Bank BUMN dengan Bank Swasta Dalam Negeri.

Saran

Saran-saran yang bisa diberikan peneliti baik untuk penelitian selanjutnya atau bagi perusahaan khususnya yang bergerak dibidang perbankan yaitu LDR dan BI Rate

Penelitian berikutnya di harapkan untuk menambah variabel independen yang berasal dari rasio likuiditas, solvabilitas dan profitabilitas, serta menambah variabel untuk faktor makro ekonominya, sehingga akan menjadi sangat valid dalam hasil analisisnya.

Penelitian selanjutnya diharapkan menggunakan sampel perusahaan perbankan yang lebih banyak lagi dan akan menjadi semakin valid hasil analisisnya.

\section{DAFTAR PUSTAKA}

Ahmad, R. Ariff, M. \& Skully, M.J 2008 The Determinant of Bank Capital Ratios in aDeveloping Economy. Asia-Pasific Financial Markets, 255 - 272

Ali et al. 20II.Bank Specific and Macroeconomic Indicators of Profitability-EmpiricalEvidence from the Commercial Bank of Pakistan. International Journal of Business and Social Science, 235-242

Alkhatib, Akram 2012.Financial Performance of Palestinian Commercial Banks. International Journal of Business and Social Science, $175-184$

Gujarati, Damodar N. 2004. Basic Econometrics.Forth Edition. E-Book Hasan et al. 2013.The Impact of Macroeconomic and Bank Specific Components on The Return of Equity. Interdisciplinary Journal of Contemporary Research in Business, 106- 126

Jacob, Jeremiah Kevin Denis. 2013. Analisis Laporan Keuangan Dengan Menggunakan Metode Camel Untuk Menilai Tingkat Kesehatan Perbankan, EMBA, 691-700

Kumbirai, Mabwe \& Robert Webb 2010.A Financial Ratio Analysis of Commercial Bank Performance in South Africa. African Review of Economic and Finance, $30-53$

Margaretha, Farah \& Diana Setianingrum 20II.Pengaruh Resiko, Kualitas Manajemen, Ukuran dan Likuiditas
Bank terhadap Capital Adequacy Ratio Bank-Bank yang Terdaftar di BursaEfek Indonesia. Jurnal Akuntansi dan Keuangan, 47 - 56

Messai, S. A., and Jouini, F. 2013. Micro and Macro Determinants of NonPerforming Loans. International Journal of Economics and Financial Issues, 852-860.

Meka, Alvin. 2015. Non-Performing Loanstingking and going out of The

Traditional Box. http://ssrn.com/abstract=261 2905

Myers, Stewart C. 1989. Signaling and Accounting Information. NBER Working Paper Series, http://www.nber.org.

Narasimhan, V.K \& Mridula Goel. 2013. Capital Adequacy and its Relevance to The IndianBanking Sector: A Study of Four Indian Banks. International Reseach Journal of Social Sciences, I - 5

Sahara, Ayu Yanita. 2013. Analisis Pengaruh Inflasi, Suku Bunga BI, dan Produk Domestik Bruto Terhadap Return On Asset (ROA) Bank Syariah di Indonesia. Jurnal Ilmu Manajemen, 149 157

Samad, A. 2004.Bahrain Commercial Bank's Performance during 1994 - 2001 . Credit and Financial Management Review, $30-40$

Sawir, 2005.Analisis Kinerja Keuangan dan Perencanaan Keuangan Perusahaan. PT. GramediaPustaka Utama, lakarta.

Sinungan, Muchdarsyah, 1992. Bank Dan

Perbankan-Manajemen, Jakarta: Rineka Cipta

Bank Indonesia 20I2. Laporan Keuangan Publikasi Bank Syariah.

Peraturan Bank Indonesia

Otoritas Jasa Keuangan 